\title{
Production and characterization of an extracellular lipase from Candida guilliermondii
}

\author{
Anne Caroline Defranceschi Oliveira ${ }^{1}$, Maria Luiza Fernandes ${ }^{2}$, André Bellin Mariano ${ }^{1}$ \\ ${ }^{1}$ Setor de Tecnologia, Núcleo de Pesquisa e Desenvolvimento de Energia Autossustentável, Universidade \\ Federal do Paraná, Curitiba, PR, Brazil. \\ ${ }^{2}$ Curso de Biotecnologia, Universidade Tuiuti do Paraná, Curitiba, PR, Brazil.
}

Submitted: September 9, 2013; Approved: June 6, 2014.

\begin{abstract}
Extracellular lipases from the endophytic yeast Candida guilliermondii isolated from castor leaves (Ricinus communis L.) were produced using low-cost raw materials such as agro-industrial residues and applying them in the esterification of oleic acid for evaluating their potential use in biodiesel production. After partial purification using ammonium sulfate, the enzyme was characterized and presented higher activity $\left(26.8 \pm 1.5 \mathrm{U} \mathrm{mL}^{-1}\right)$ in the presence of $5 \mathrm{mmol} \mathrm{L}^{-1} \mathrm{NaCl}$ at $30^{\circ} \mathrm{C}$ and $\mathrm{pH} 6.5$. The production through submerged fermentation was formerly performed in $150 \mathrm{~mL}$ erlenmeyer flasks and, once the enzyme production was verified, assays in a $14 \mathrm{~L}$ bioreactor were conducted, obtaining $18 \pm 1.4 \mathrm{U} \mathrm{mL}^{-1}$. The produced enzyme was applied in the oleic acid esterification under different solvents: hexane, cyclohexane or cyclohexanone) and different acid:alcohol molar ratios. Higher ester conversion rate (81\%) was obtained using hexane and the molar ratio of 1:9 was the best conditions using methanol. The results suggest the potential for development of endophytic yeast in the production of biocatalyst through submerged fermentation using agroindustrial residues as culture medium.
\end{abstract}

Key words: extracellular lipase, endophytic yeast, esterification, submerged fermentation, bioreactor.

\section{Introduction}

Lipase (triacylglycerol hydrolase EC 3.1.1.3) are hydrolytic enzymes capable of cleaving the ester bond of triacylglycerol, and catalyze ester synthesis in vitro by shifting equilibrium of reaction (Contesini et al., 2010; Fernandes et al., 2007; Li and Zong, 2010; Mohamed et al., 2011). Some advantages of using these enzymes in the cleavage and synthesis of esters bonds are: they do not require co-factors, they have great stability and activity in organic media, they work in a wide variety of substrates and they exhibit high specificity and enantioselectivity (Bussamara et al., 2010; Hernandez-Rodrigues et al., 2009). These enzymes can be obtained from several organisms; however, microorganisms are most promising for this purpose (Fernandes et al., 2007; Salihu et al., 2012). Among the microorganisms, yeasts have been used widely for the production of these enzymes, with special emphasis on the genus Candida sp. (De María et al., 2006; Salihu et al., 2011; Sharma et al., 2001).

In this case, it is necessary to provide to the microorganism suitable conditions that allow their growth and induce the production of the metabolite of interest. Culture media used for this purpose are usually expensive, which results in a high cost for enzyme production. Nevertheless, the use of agro-industrial residues as substrate for fermentation processes and support are a trend in recent publications, a fact that leads to reduction of production cost of these biocatalysts and can thus make them economically competitive against chemical catalysts (Damasso et al., 2008; Salihu et al., 2011). In previous work, our research group demonstrated the feasibility of the production of microbial lipases in shake flasks by applying a low cost fer- 
mentation media, obtaining yields of up to $25 \mathrm{U} \mathrm{mL}^{-1}$ of lipase activity (Oliveira et al., 2012).

Within the broad application field of lipases, synthesis of biodiesel is attracting great interest (Gog et al., 2012; Hasan et al., 2006). The biodiesel is a biofuel produced from renewable sources consisting of alkyl esters of fatty acids obtained from the esterification or transesterification of various types of lipids, and its use is increasing due to the scarcity of fossil fuels used for diesel obtainment (Gog et al., 2012; Tan et al., 2012). Besides, the biodiesel presents interesting features such as their possibility of use in diesel engines without any adjustments and also the reduction of some gases that contribute to the greenhouse effect (Bajaj et al., 2010; Lai et al., 2011).

In the traditional biodiesel production, for economic reasons, homogeneous catalysts are commonly used providing high product conversion. The enzymes generally exhibit slower reactions, but have major advantages over the prior process, such as high product purity, easy separation of the catalyst from the reaction medium, mild reaction temperatures, and easier glycerol separation from biodiesel (Diaz et al., 2006; Iftikhar et al., 2010; Tran et al., 2012).

Endophytic bacteria and yeast in plants are alternative resources for isolating new microorganisms producing useful enzymes (Molina et al., 2012; Fang et al., 2006). However, despite the potential for industrial application, few studies have been realized on extracellular lipases from endophytic yeast (Oliveira et al., 2013; Oliveira et al., 2012; Panuthai et al., 2012; Venkatesagowda et al., 2012; Costa-Silva et al., 2011; Torres et al., 2003).

In this paper, we report the production of lipases using an endophytic yeast Candida guilliermondii isolated from leaves from castor bean plant (Ricinus communis, L.). The enzyme was partially purified and its lipolytic activity measured in terms of effect of $\mathrm{pH}$, temperature and different ions. The production of (m)ethyl oleate under different solvents and acid:alcohol molar ratios were also investigated.

\section{Materials and Methods}

\section{Cultivation and identification of lipase-production yeast}

The enzyme production was performed by submerged fermentation $(\mathrm{SmF})$ employing an endophytic yeast strain isolated from the castor bean leaves (Ricinus communis L.), kindly provided by Roseli Mello, researcher from Tuiuti University of Paraná. The yeast Candida guilliermondii was phenotypically characterized by standard morphological and biochemical tests as carbon and nitrogen assimilation, and ability to ferment carbohydrates, as described by Guimarães (2006).

The yeast was grown in medium containing brewer's yeast $\left(20\right.$ g. $\left.\mathrm{L}^{-1}\right)$ and sucrose $\left(30\right.$ g. $\left.\mathrm{L}^{-1}\right)$ for $120 \mathrm{~h}$, and after this period the cell concentration was determined by Neu- bauer chamber counting. The fermentation was conducted in $250 \mathrm{~mL}$ Erlenmeyer flasks containing $150 \mathrm{~mL}$ of fermentative medium. This medium was composed of ammonium sulfate 15 g.L. $\mathrm{L}^{-1}$, manganese sulfate 0.15 g.L $\mathrm{L}^{-1}$, brewer's yeast 10 g.L. $\mathrm{L}^{-1}$, Tween 808 g.L. $\mathrm{L}^{-1}$, glycerol 15 g.L. $\mathrm{L}^{-1}$ and soybean oil 30 g.L $\mathrm{L}^{-1}$, dissolved in phosphate buffer $25 \mathrm{mmol}$ $\mathrm{L}^{-1}$ at $\mathrm{pH}$ 6.5. After sterilization, the yeast was added to the fermentative medium at a final concentration of $10^{7}$ cells. $\mathrm{mL}^{-1}$. The fermentation was maintained in a shaker at $30^{\circ} \mathrm{C}$ at $180 \mathrm{rpm}$ for $72 \mathrm{~h}$.

\section{Lipase assay}

The lipase assay was determined by the pNPP (pnitrophenyl palmitate) hydrolysis method, described by Ghori et al. (2011) adapted to this work. A $100 \mu \mathrm{L}$ sample of the fermented medium was incubated for $5 \mathrm{~min}$ at $30^{\circ} \mathrm{C}$ with $800 \mu \mathrm{L}$ of $0.25 \%$ PVA [poly(vinyl alcohol)] solution in $\mathrm{pH} 6.5$ phosphate buffer and $100 \mu \mathrm{L}$ of $8 \mathrm{mmol} \mathrm{L}^{-1} \mathrm{pNPP}$ solution in isopropanol. After the incubation time, the reaction was stopped by $500 \mu \mathrm{L}$ of $3 \mathrm{~mol} \mathrm{~L}^{-1} \mathrm{HCl}$ solution, then the mixture was centrifuged and $500 \mu \mathrm{L}$ of the supernatant was added to $1 \mathrm{~mL}$ of $2 \mathrm{~mol} \mathrm{~L}^{-1} \mathrm{NaOH}$ solution. The absorbance was measured in a spectrophotometer under $410 \mathrm{~nm}$. One unit of enzymatic activity (U) was defined as the release of $1 \mu \mathrm{mol}$ of $\mathrm{pNP}$ per minute.

\section{Lipase characterization}

The conditions for lipolytic activity evaluation were the same as describe above, varying only the parameters to be assessed. The optimal $\mathrm{pH}$ was determined using $\mathrm{pNPP}$ as the substrate in buffer solutions of $\mathrm{pH}$ values ranging 5.0-5.5 (acetate buffer), 6.0-7.5 (phosphate buffer) and 8.0-8.5 (Tris - $\mathrm{HCl}$ buffer). The optimal temperature for lipolytic activity was determined using pNPP as a substrate at different temperatures $\left(20,30,37,45\right.$ and $\left.55^{\circ} \mathrm{C}\right)$. The influence of ions on enzyme activity was observed by adding ions $\left(\mathrm{Fe}^{3+}, \mathrm{Mg}^{2+}, \mathrm{Mn}^{2+}, \mathrm{K}^{+}, \mathrm{Na}^{+}, \mathrm{Ca}^{2+}, \mathrm{Zn}^{2+}\right)$ or EDTA $\left(1\right.$ and $\left.5 \mathrm{mmol} \mathrm{L}^{-1}\right)$ to the lipase assay. The results of the lipase characterization experiments were expressed as Residual Lipolytic Activity [RLA (\%)], in which the value obtained in the analysis $\left[L A_{\text {assay }}\right]$ was divided by the maximum activity determined in the optimal condition of $\mathrm{pH}$ and temperature tested $\left[L A_{\text {control }}\right]$, as follows:

$$
R L A(\%)=\frac{L A_{\text {assay }}}{L A_{\text {control }}}
$$

\section{Simple bioreactor batch fermentation}

Larger scale submerged fermentation (Figure 1) was performed after the lipase characterization study. The fermentation medium was similar to that described for the lipase production in Erlenmeyer flaks (2.1.). The bioreactor consisted of a simple glass reactor of $20 \mathrm{~L}$ in which was added $14 \mathrm{~L}$ of fermentative medium. The bioreactor and the fermentative medium were sterilized by autoclaving previ- 

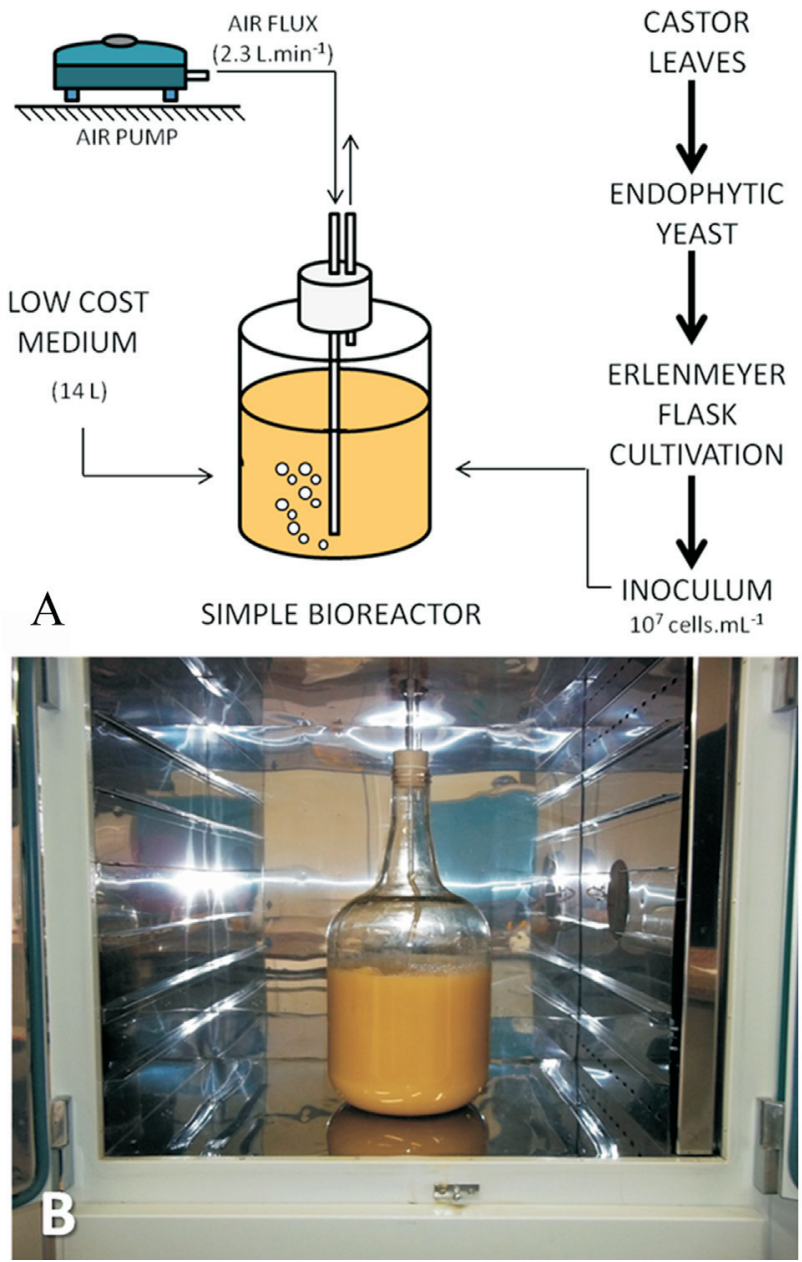

Figure 1 - Diagram (A) and picture (B) of simple bioreactor batch SmF to grown endophytic yeast to produce extracellular lipase.

ously to the addition of the yeast in a final concentration of $10^{7}$ cells. $\mathrm{mL}^{-1}$. This system was kept in an incubator at $30{ }^{\circ} \mathrm{C}$ for $72 \mathrm{~h}$. A silicone tube previously sterilized was inserted to the bottom of the bioreactor and connected to an air compressor providing $2.3 \mathrm{~L}$ of air $\mathrm{min}^{-1}$. There was no mechanical procedure to agitate the system besides the agitation provided by the air injection and no $\mathrm{pH}$ control was performed during the experiment as well. The lipase production in this bioreactor was repeated three times.

\section{Partial purification of the enzyme}

After fermentation, the enzyme was partially purified by solid ammonium sulfate precipitation. The precipitation was performed on an ice bath using the saturation levels of $50,60,70$ and $80 \%$. In the ranges of 50 to $70 \%$ irrelevant lipolytic activities were recovered, so these salt concentrations were discarded. The enzyme precipitated in the range of saturation of $80 \%$ showed higher lipolytic activity and, therefore, was used in this study. The precipitant was suspended with a minimal amount of distilled water and then dialyzed in distilled water for $48 \mathrm{~h}$ at $4{ }^{\circ} \mathrm{C}$. The dialyzed material was freeze-dried.

\section{Assessment of syntheses of (m)ethyl oleate via esterification of oleic acid}

Syntheses of methyl and ethyl oleate were performed in $125 \mathrm{~mL}$ Erlenmeyer flasks. To each flask were added the equivalent of 2000 Units of lyophilized enzyme, $50 \mathrm{mmol} \mathrm{L}^{-1}$ oleic acid, $200 \mathrm{mmol} \mathrm{L}^{-1}$ ethanol or methanol and $15 \mathrm{~mL}$ of organic solvent. Three organic solvents were evaluated to perform the synthesis: hexane, cyclohexane and cyclohexanone. The reactions were incubated in a shaker at $30^{\circ} \mathrm{C}$ and $180 \mathrm{rpm}$ for $72 \mathrm{~h}$. The acid:alcohol proportions $1: 6 ; 1: 9$ and $1: 12$ were also investigated in experiments after determination of the organic solvent with the best performance.

\section{Ester conversion determination}

The methodology described by Lowry-Tinsley (1976) was carried out to determine the fatty acids conversion into esters. This method was used previously and has great precision in the quantification of fatty acids (Oliveira et al., 2012; Fernandes et al., 2007; Baron et al., 2005). The technique is based on the bond between free fatty acids and copper II ions under organic media, which allows the measurement of the percentage of fatty acids converted to ester. A volume of $0.2 \mathrm{~mL}$ of reaction medium was added to $2.4 \mathrm{~mL}$ of toluene and $0.5 \mathrm{~mL}$ of pyridine and copper acetate $(5 \%)$. The reactions were vortexed for $30 \mathrm{~s}$ and the organic phase read in spectrophotometer at $715 \mathrm{~nm}$. Thus, the determination of ester conversion rate $[C(\%)]$ was calculated based on the following equation:

$$
C(\%)=\left(1-\frac{O A_{f}}{O A_{i}}\right) \times 100
$$

where $O A_{f}$ correspond to final concentration of oleic acid after the reaction and $O A_{i}$ correspond to initial concentration of oleic acid previously the esterification reaction (50 $\left.\mathrm{mmol} \mathrm{L}{ }^{-1}\right)$.

\section{Statistical analysis}

All experiments were carried out independently in triplicate. All measurements were taken in triplicate. Steady-state conditions were reached after $30 \mathrm{~min}$ before starting all the experiments. The accuracy limit was calculated as being twice the standard deviation of these measurements with a confidence level of $95 \%$.

\section{Results and Discussion}

\section{Enzyme production}

The lipolytic activity observed in the fermented medium after growth of yeast in Erlenmeyer flasks under agitation reached values of $20 \pm 2.4 \mathrm{U} \mathrm{mL}^{-1}$. After verifying that the yeast was able to secrete enough quantity of lipases 
in Erlenmeyer flasks, production on a simple bioreactor (14 L) were conducted in order to evaluate the ability of the biocatalyst production on a larger scale. The lipolytic activity obtained in these experiments were $18 \pm 1.4 \mathrm{U} \mathrm{mL}^{-1}$, results quite similar to that obtained in shake flasks, demonstrating that the enzyme production on a large scale may indeed be feasible.

The price of the biocatalyst is one of the limiting factors for its use in the synthesis of esters, since the prices of chemical catalysts are much more affordable. To lower the cost of production of enzymes some procedures can be adopted, such as the use of waste and low cost substrates for its production (Salihu et al., 2012). In this work, it was used low cost sources of nutrients such as glycerol, which is a residue of biodiesel production, the residuum from beer yeast and ammonium sulfate. Another substrate that has been modified in the cultivation medium was olive oil. This oil is commonly used as an inducer for the lipase secretion but, in this case, was replaced by soybean oil that, besides the lower cost, it has high availability in Brazil, which becomes relevant for a large scale production. For formulating the composition of medium used in this study, traditional raw materials such as glucose, yeast extract and olive oil (U.S. dollar $3 \mathrm{~L}^{-1}$, costs calculated based on prices in Brazil - August 2013) were replaced by glycerol, brewer's yeast and soybean oil, resulting in a $48 \%$ reduction in the cost of materials.

The replacement of high cost components in the culture medium by substances of lower value can even result in increased productivity as the results published by Damasso et al. (2011), in which the substitution of olive oil by residues from oil processing corn to produce fungal lipases during SSF resulted in 30\% increase in enzyme production.

Another aspect that should be evaluated is the production of the biocatalyst on a larger scale in order to supply a large demand. The production in bioreactors is still poorly explored, and this is a major step for further industrial processing (Sharma et al., 2001). Microorganisms are very sensitive to the environment to which they are exposed, and simply increasing the volume of the same fermentation medium does not mean a successful large-scale production. Several factors must be appropriate to the system, in particular the ideal aeration and agitation. In this case, it was observed that the variation of the conditions for microorganism cultivation provided by using shake flasks or a simple bioreactor resulted in the achievement of similar lipolytic activity.

Bussamara et al. (2010) produced lipases in yeast bioreactor with the same operational volume used in this study (14 L), but with $\mathrm{pH}$ control and higher agitation provided by shovels and rotors. They obtained about $1.2 \mathrm{U} \mathrm{mL}^{-1}$, approximately $7 \%$ of the production observed in this article.

On the other hand, the use of $\mathrm{pH}$ control in small bioreactors (3 L) by Iftikhar et al. (2010) resulted in an in- crease of $124 \%$ compared to shake flasks. Therefore, more studies are needed to verify the dependence of control mechanisms, such as $\mathrm{pH}$ and agitation on the production of enzymes in bioreactors. The ability of this yeast to produce enzymes in simple bioreactor and without control, as well as the use of culture medium composed of low-cost materials suggests the potential of this endophytic yeast to be used for production of large-scale biocatalysts with competitive prices.

\section{Lipase characterization}

After partial purification of the enzyme through solid ammonium sulfate precipitation, the lipolytic activity of dialyzed material was evaluated under controlled conditions of different temperature, $\mathrm{pH}$ and ions to determine the best conditions for enzymatic catalysis. The optimum $\mathrm{pH}$ value was 6.5 (Figure 2) and the optimum temperature was $30^{\circ} \mathrm{C}$ (Figure 3 ). These two optimum values coincide with the optimal parameters for yeast growth. Most microbial enzymes have characteristics such as optimum $\mathrm{pH}$ and temperatures of their micro-secreting organisms. Yeast have a range of optimum growth at $\mathrm{pH}$ slightly acidic and temperatures between $28-30{ }^{\circ} \mathrm{C}$, providing these features to their apparatuses metabolic (Contesini et al., 2010; Salihu et al., 2011; Sharma et $a l ., 2001)$. It can be observed that the enzyme loses $70 \%$ of its activity when incubated at $55^{\circ} \mathrm{C}$. However, the low thermal stability lcan be overcome by enzyme immobilization. Cui et al. (2013) enhanced thermal stability for the immobilization preparations compared with that for free preparations when working with Yarrowia lipolytica lipase Lip2 by immobilization on polyethyleneimine-coated polyurethane foam. Forsyth and Patwardhan (2012) also reported increased thermal stability of Candida antarctica lipase B after immobilization on bioinspired silica.

The lipolytic activity of the partially purified enzyme was assayed in the presence of different concentrations of mono, di and trivalent ions and the results are shown in Table 1. Experiments conducted in the presence of monovalent ions $\left(\mathrm{Na}^{+}\right.$and $\mathrm{K}^{+}$) showed that $5 \mathrm{mmol} \mathrm{L}{ }^{-1} \mathrm{Na}^{+}$caused an increase in enzyme activity (49\%) and $\mathrm{K}^{+}$caused no change in lipolytic activity measured. Effects of monovalent ions have also been investigated previously in lipase produced by Pseudozyma hubeiensis (Bussamara et al., 2010), who reported that $20 \mathrm{mmol} \mathrm{L}^{-1} \mathrm{~K}^{+}$resulted in increased activity. As seen in previously published work (Ghori et al., 2011; Kamini et al., 2000), most microbial lipases are not metal-dependent and thus suffer little change in its activity in the presence of divalent ions at low concentrations. This same phenomenon has been observed in this experiment to determine the lipolytic activity under the presence of $\mathrm{Zn}^{2+}$, $\mathrm{Mg}^{2+}, \mathrm{Mn}^{2+}$ or $\mathrm{Ca}^{2+}$, which the ion concentrations of 1 and 5 mmol L ${ }^{-1}$ barely have affected the observed results. Experiments performed in the presence of $5 \mathrm{mmol} \mathrm{L}^{-1} \mathrm{Fe}^{3+}$ showed an inhibitory effect of approximately $44 \%$ in lipolytic activ- 


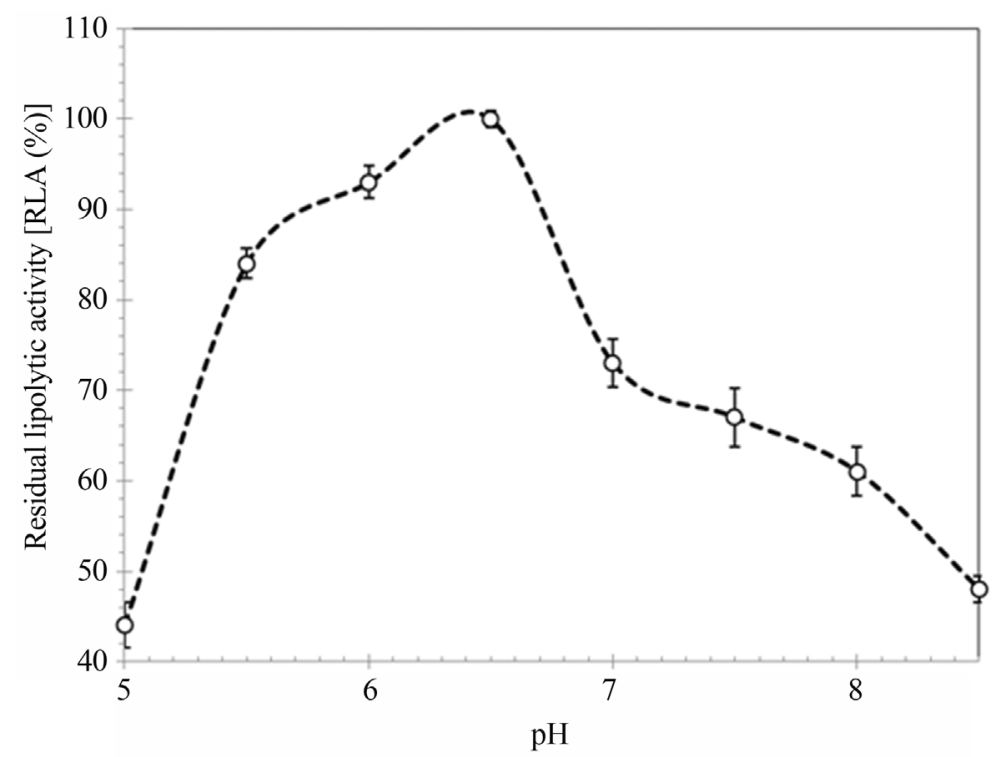

Figure 2 - Determination of optimal pH for extracellular lipase obtained from submerged fermentation of endophytic yeast Candida guilliermondii. $100 \%$ Residual lipolytic activity correspond to $18 \mathrm{U} \mathrm{mL}^{-1}$ determined in optimal conditions ( $\mathrm{pH} 6.5$ and $30^{\circ} \mathrm{C}$ ). The results expressed correspond to average of three independent experiments conducted and analyses made in triplicate. The length of each error bar is twice the standard deviation of the activity measured.

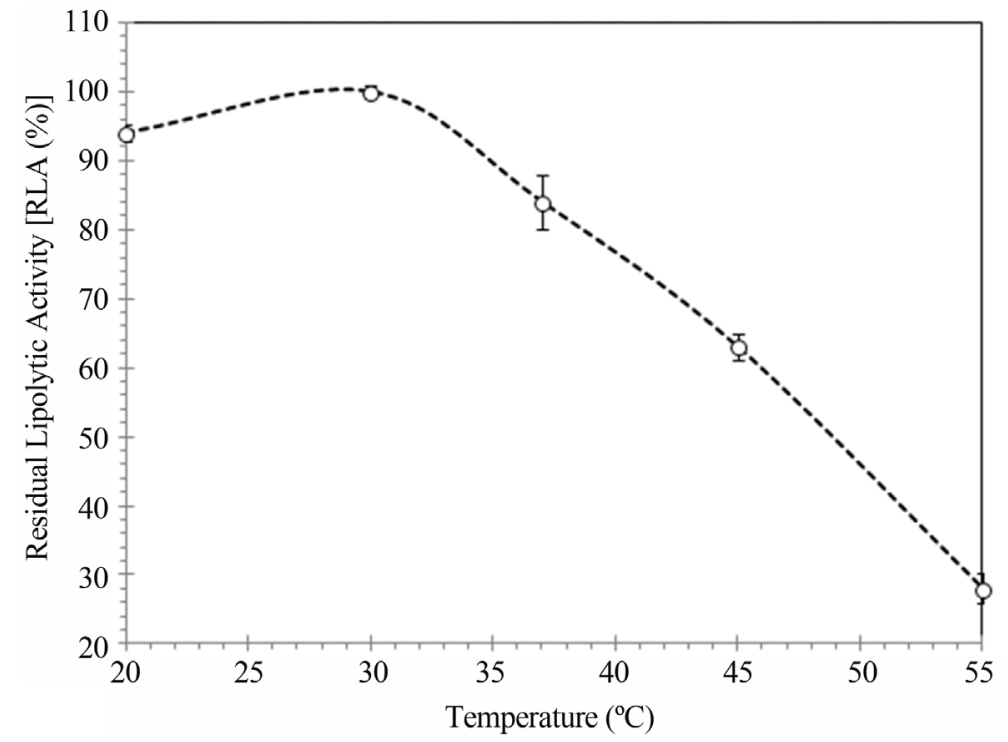

Figure 3 - Determination of the optimum temperature for extracellular lipase obtained from submerged fermentation of endophytic yeast Candida guilliermondii. $100 \%$ Residual lipolytic activity correspond to $18 \mathrm{U} \mathrm{mL}^{-1}$ determined in optimal conditions (pH 6.5 and $30{ }^{\circ} \mathrm{C}$ ). The results expressed correspond to average of three independent experiments conducted and analyses made in triplicate. The length of each error bar is twice the standard deviation of the activity measured.

ity. Furthermore, the addition of EDTA (1 and $\left.5 \mathrm{mmol} \mathrm{L}^{-1}\right)$ did not alter the results.

\section{Syntheses of $(m)$ ethyl oleate via esterification of oleic acid}

After the characterization of the lipolytic activity under different conditions, the partially purified enzyme obtained from Candida guilliermondii was evaluated for its potential as a catalyst for synthesis of biodiesel. In this studies, oleic acid was used as substrate for the synthesis of (m)ethyl oleate evaluating the effect of different non-polar solvents and different molar ratios of acid: alcohol.

\section{Effect of non-polar solvent}

In enzymatic reactions catalyzed by lipases, the presence of water promotes the hydrolysis reaction. In this sense, nonpolar organic solvents are commonly used in biocatalysis using lipases because the reaction equilibrium 
Table 1 - Effect of ions on lipase activity of Candida guilliermondii.

\begin{tabular}{lcc}
\hline Ions & \multicolumn{2}{c}{ Residual Lipolytic Activity $[R L A(\%)]$} \\
\cline { 2 - 3 } Control $^{*}$ & $1 \mathrm{mmol} . \mathrm{L}^{-1}$ & $5 \mathrm{mmol} . \mathrm{L}^{-1}$ \\
$\mathrm{KCl}$ & $100 \pm 1.9$ & $100 \pm 1.9$ \\
$\mathrm{NaCl}$ & $101.3 \pm 2.3$ & $99.3 \pm 4.7$ \\
$\mathrm{ZnCl}_{2}$ & $105.6 \pm 4.7$ & $148.9 \pm 8.4$ \\
$\mathrm{FeCl}_{3}$ & $101.2 \pm 10.4$ & $96.3 \pm 4.4$ \\
$\mathrm{MgCl}_{2}$ & $91.1 \pm 5.5$ & $66.2 \pm 6.9$ \\
$\mathrm{CaCl}_{2}$ & $100 \pm 1.5$ & $100 \pm 10.2$ \\
$\mathrm{MnCl}_{2}$ & $97.1 \pm 7.9$ & $92.1 \pm 1.6$ \\
$\mathrm{EDTA}$ & $100 \pm 2.5$ & $105.8 \pm 3.4$ \\
\hline
\end{tabular}

$* L A_{\text {control }}=$ Lipase activity determined in optimal conditions $(\mathrm{pH} 6.5$ and $30{ }^{\circ} \mathrm{C}$ ) without addition of ions or EDTA correspondent to $18 \mathrm{U} \mathrm{mL}^{-1}$. The results expressed correspond to average of three independent experiments conducted and analyses made in triplicate. The error corresponds to twice the standard deviation of the measured data.

moving towards the synthetic route (Gog et al., 2012, Faber, 2011, Fernandes et al., 2007).

The action of organic solvents in enzyme catalysis occurs primarily at three levels: a) by direct interaction with the enzyme, changing its native conformation by rupture of hydrogen bonds and hydrophobic interactions, b) by interaction with substrates and products reaction, affecting their solubility and diffusion or directly participating in the reaction, c) by interaction with the water layer hydration of the enzyme and its removal (Hernández-Rodríguez et al., 2009). The most important factor for the balance between stabilization and inactivation of enzymes due to the presence of the organic phase consists of solvent polarity. A reliable measure of polarity is the logarithm of the partition coefficient $(\log \mathrm{P})$ of a compound in the two phases of a mixture of hydrophobic liquid (n-octanol) and a hydrophilic liquid (water). The higher the value of $\log \mathrm{P}$, the more hydrophobic is the solvent (Laane et al., 1987). Generally, the enzyme activity is relatively low in hydrophilic solvents $(\log \mathrm{P}<2)$ because the solvents can denature the enzymes by penetrating into the hydrophobic core of the protein modifying the natural structure. This effect is moderate in solvents with $\log \mathrm{P}$ between 2 and 4 and it is high in non-polar solvents, where $\log \mathrm{P}>4$ (Faber, 2011).

Thus, the ester conversion rate for the synthesis reaction of (m)ethyl oleate were assessed the effects of two non-polar solvents [hexane $(\log \mathrm{P}=3.5)$ and cyclohexane $(\log \mathrm{P}=3.2)$ ] and a slightly water-miscible solvent [cyclohexanone $(\log \mathrm{P}=0.81)]$ and the results of these analyzes are shown in Figure 4.

For systems consisting of hexane and cyclohexane, methyl ester conversions were similar: 68 and 64\%, respectively. When cyclohexanone was used, the conversion to esters of oleic acid was reduced to less than $30 \%$. Such a solvent, though having the same carbon number of the other solvents tested, has a different characteristic conferred by grouping ketone, a partial solubility in water. Enzymes are polar molecules, so they require a protective layer of water to maintain their three-dimensional conformation. Solvents with a certain polarity remove these water molecules, essential for enzyme function, thereby modifying its threedimensional structure and, causing denaturation of the biocatalyst (Hernández-Rodriguez et al., 2009; Pandey et al., 1999). Aragão et al. (2009) performed the synthesis of isoamyl butyrate ester using lipase and found that in systems containing acetone as solvent the reaction did not occurred. In this case, this high polarity solvent removed

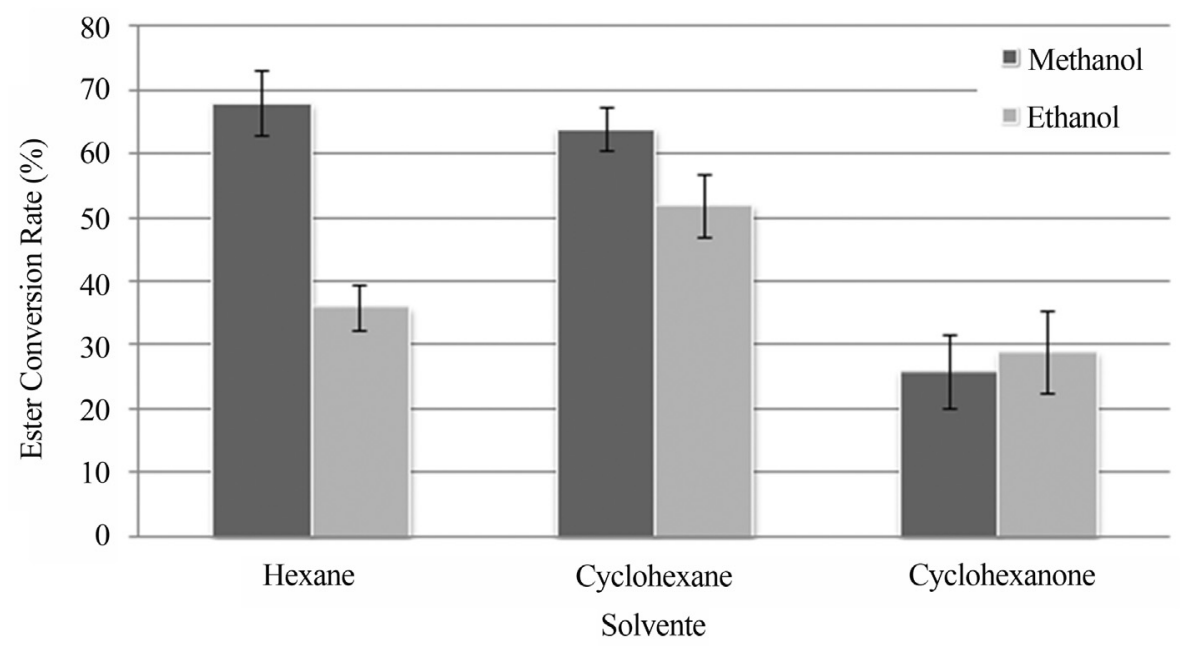

Figure 4 - Effect of solvents in ester conversion rate $[C(\%)]$ to reactions catalyzed by lipase isolated from Candida guilliermondii. The experiments were carried out in the presence of different solvents (hexane, cyclohexane and cyclohexanone) using oleic acid and methanol or ethanol as substrates with 1:9 molar ratio. The results expressed correspond to average of three independent experiments conducted and analyses made in triplicate. The length of each error bar is twice the standard deviation of the activity measured. 


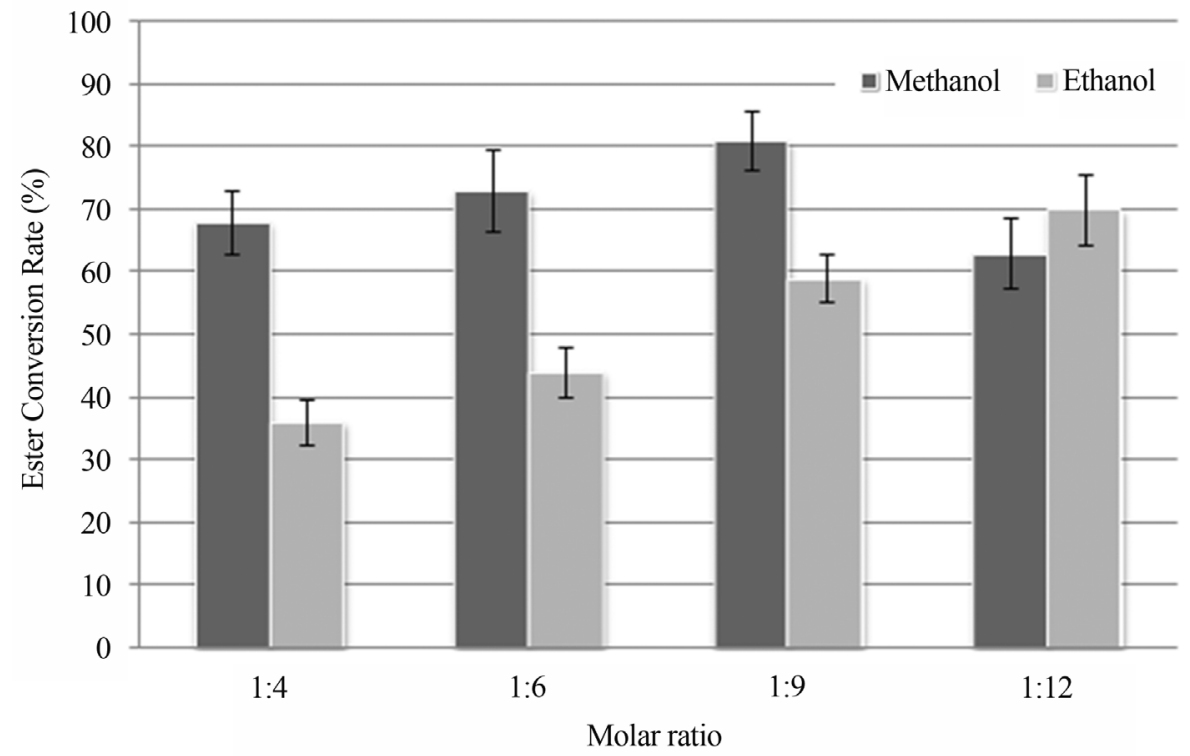

Figure 5 - Effect of acid:alcohol molar ration in ester conversion rate $[C(\%)]$ to reactions catalyzed by lipase isolated from Candida guilliermondii. The experiments were carried out in the presence hexane as solvent using oleic acid and methanol or ethanol as substrates, with 1:4, 1:6, 1:9 or 1:12 molar ratio. The results expressed correspond to average of three independent experiments conducted and analyses made in triplicate. The length of each error bar is twice the standard deviation of the activity measured.

water molecules responsible for hydration of enzyme in its native conformation, thereby causing its denaturation.

\section{Effect of alcohol and different acid:alcohol molar ratios}

To evaluate the effect of the proportion of oleic acid in relation to alcohol in the ester synthesis reactions, hexane was chosen as solvent due to its better performance after the evaluation of solvents ( $68 \%$ ester conversion rate). The use of methanol as substrate resulted in higher yields for ester conversion rates compared to ethanol when a molar ratio of $1: 6$ and 1:9 were performed. The highest yield of reaction ( $81 \%$ conversion rate) was obtained with a molar ratio of $1: 9$, as shown in Figure. 5. The conversion rate can be increased by $43 \%$ by enzyme immobilizing on activated silica, as previously published (Oliveira et al., 2012). When tested for the esterification of fatty acids isolated from microalgae Scenedesmus sp. and under the same reaction conditions proposed for the esterification of oleic acid, Candida guilliermondii lipase showed conversion rate of $46 \%$ after $12 \mathrm{~h}$.

The percentage of esterification using ethanol has been increased due to the increase of the molar ratio, showing that the reaction can achieve higher levels. However, the use of large amounts of ethanol would make the process expensive and ethanol is most difficult to be recovered from the reaction medium (Gog et al., 2012; HernándezRodríguez et al., 2009). Yet, the study of increase ester conversion rates using ethanol as in the enzymatic esterification reactions must be encouraged because of the renewability characteristics in using this alcohol detrimental to the use of methanol.
Methanol generally has superior performance to ethanol for the synthesis of esters by chemical means due to its greater reactivity, and because of this alcohol being easier to be recovered from the reaction medium, which leads to a cheaper process (Gog et al., 2012; Guan et al., 2010). The enzymatic synthesis using methanol varies for each enzyme, some of which are completely denatured in the presence of this alcohol due to its higher polarity (Tan et al., 2010). On the other hand, the enzymes of this study show tolerance to this alcohol and, in this case, the most suitable for this reaction.

\section{Conclusions}

It was shown that partially purified enzyme containing lipolytic activity, produced by submerged fermentation in a lower cost cultivation medium by endophytic yeast Candida guilliermondii, can be used as a catalyst for the production of methyl oleate using methanol as substrate. The esterification of oleic acid with ethanol is also possible, although higher molar ration were required. Moreover, the outcomes contribute to the development of technologies to increase the scale of lipase production in an economically attractive way by using agroindustrial low-value products as culture medium and bioreactor without automation.

\section{Acknowledments}

This study was supported by the Brazilian funding agencies Conselho Nacional de Desenvolvimento Científico e Tecnológico (CNPq - projects 552867/2007-1, 574759/2008-5, 558835/2010-4 and 485058/2012-0) and Coordenação de Aperfeiçoamento de Pessoal de Nível Su- 
perior (CAPES). Their support is greatly appreciated. The authors would like to acknowledge Felipe Miguel Farion Watanabe for critical evaluation and proof reading the manuscript, Universidade Tuiuti do Paraná (UTP) and Universidade Federal do Paraná (UFPR) for infrastructural support and the Postgraduate Programme in Engineering and Materials Science (PIPE - UFPR).

\section{Nomenclature and Abbreviation}

$C(\%)$ : ester conversion rate $(\%)$

EDTA: ethylenediamine tetraacetic acid

$L A_{\text {assay }}$ : lipolytic activity in the analysis $\left(\mathrm{U} \mathrm{mL}^{-1}\right)$

$L A_{\text {control }}$ : lipolytic activity in optimal condition of $\mathrm{pH}$ and temperature $\left(\mathrm{U} \mathrm{mL}^{-1}\right)$

$\log$ P: logarithm of the partition coefficient

$O A_{f}$ : final concentration of oleic acid $\left(\mathrm{mmol} \mathrm{L}^{-1}\right)$

$O A_{i}$ : initial concentration of oleic acid $\left(\mathrm{mmol} \mathrm{L}^{-1}\right)$

pNP: p-nitrophenol

pNPP: p-nitrophenyl palmitate

PVA: poly(vinyl alcohol)]

$R L A$ : residual lipolytic activity (\%)

SSF: solid state fermentation

SmF: submerged fermentation

$\mathrm{U}$ : one unit of enzymatic activity (release of $1 \mu \mathrm{mol}$ of $\mathrm{pNP}$ per minute)

\section{References}

Aragão VC, Anschau A, Porciuncula BDA, Thiesen C, Kalil SJ, Burkert CAV, Burkert JFM (2009) Enzymatic synthesis isoamyl butyrate employing commercial microbial lipases. Quim Nova 32:2268-2272.

Bajaj A, Lohan P, Jha PN, Mehrotra R (2010) Biodiesel production through lipase catalyzed transesterification: An overview. J Mol Catat B:Enzym 62:9-14.

Baron AM, Sarquis MIM, Baigori M, Mitchell DA, Krieger N (2005) A comparative study of the synthesis of n-butyloleate using a crude lipolytic extract of Penicillum coryophilum in water-restricted environments. J Mol Catal B:Enzym 34:25-32.

Bussamara R, Fuentefria AM, Oliveira ES, Broetto L, Simcikova M, Valente P, Schrank A, Vainstein MH (2010) Isolation of a lipase-secreting yeast for enzyme production in a pilotplant scale batch fermentation. Biores Technol 101:268-275.

Contesini FJ, Lopes DB, Macedo GA, Nascimento MG, Carvalho PO (2010). Aspergillus sp. lipase: potencial biocatalyst for industrial use. J Mol Catal B:Enzym 67:163-171.

Costa-Silva TA, Nogueira MA, Souza CRF, Oliveira WP, Said S (2011) Lipase production by endophytic fungus Cercospora kikuchii: stability of enzymatic activity after spray drying in the presence of carbohydrates. Drying Technol 29:11121119.

Cui CX, Tao YF, Li LL, Chen BQ, Tan TW (2013) Improving the activity and stability of Yarrowia lipolytica lipase Lip2 by immobilization on polyethyleneimine-coated polyurethane foam. J Mol Catal B:Enzym 91:59-66.
Damasso MCT, Passionoto MA, Freitas SC, Freire DMG, Lago RCA, Couri S (2008) Utilization of agroindustrial residues for lipase production by solid-state fermentation. Braz J Microbiol 39:676-681.

De María PD, Sánchez-Montero JM, Sinisterra JV, Alcántara AR (2006) Understanding Candida rugosa lipases: an overview. Biotechnol Adv 24:180-196.

Diaz JCM, Rodríguez S, Roussos J, Cordova J, Abousalham A, Carriére F, Baratti J (2006) Lipases from the thermotolerant fungus Rhizopus homothallicus is more thermostable when produced using solid state fermentation than liquid fermentation procedures. Enzyme Microb Technol 39:1042-1050.

Faber K (2011) Biotransformations in Organic Chemistry - A Textbook. $6^{\text {th }}$ edition. Springer, Berlin.

Fang Y, Lu Z, Lv F, Bie X, Liu S, Ding Z, Xu W (2006) A newly isolated organic solvent tolerant Staphylococcus saprophyticus M36 produced organic solvent-stable lipase. Curr Microb 53:510-515.

Fernandes MLM, Saad EB, Meira JA, Ramos LP, Mitchell DA, Krieger N (2007) Esterification and transesterification reactions catalysed by addition of fermented solids to organic reaction media. J Mol Catal B:Enzym 44:8-13.

Forsyth C, Patwardhan SV (2013) Controlling performance of lipase immobilised on bioinspired silica. J Material Chem B 1:1164-1174.

Ghori MI, Iqbal MJ, Hamed A (2011) Characterization of a novel lipase from Bacillus sp. isolated from tannery wastes. Braz J Microbiol 42:22-29.

Gog A, Roman M, Tos M, Paizs C, Irimie FD (2012) Biodiesel production using enzymatic transesterification - current state and perspectives. Renew Energy 39:10-16.

Guan F, Peng P, Wana G, Yin T, Peng Q, Huang J, Guan G, Li Y (2010) Combination of two lipases more efficiently catalyzes methanolysis of soybean oil for biodiesel production in aqueous medium. Process Biochem 45:1677-1682.

Guimarães TM, Moriel DG, Machado IP, Picheth CMTF, Bonfim TMB (2006) Isolation and characterization of Saccharomyces cerevisiae strains of winery interest. RBCF 42:119-126.

Hasan F, Shah AA, Hameed A (2006) Industrial applications of microbial lipases. Enzyme Microb Technol 39:235-251.

Hernandez-Rodriguez B, Córdova J, Barzana E, Favela-Torres E (2009) Effects of organic solvents on activity and stability of lipases produced by thermotolerant fungi in solid-state fermentation. J Mol Catal B:Enzym 61:136-142.

Iftikhar T, Niaz M, Zia MA, Haq I (2010) Production of extracellular lipases by Rhizopus oligosporus in a stirred fermentor. Braz J Microbiol 41:1124-1132.

Kamini NR, Fujii T, Kurosu T, Iefuj H (2000). Production, purification and characterization of an extracellular lipase from the yeast Cryptococcus sp. S-2. Process Biochem 36:317324.

Laane C, Boeren S, Vos K, Veeger C (1987) Rules for optimization of biocatalysis in organic solvents. Biotechnol Bioeng 30:81-87.

Lai JQ, Hu ZL, Wang PW, Yang Z (2011) Enzymatic production of microalgal biodiesel in ionic liquid [BMIm] $\left[\mathrm{PF}_{6}\right]$. Fuel 95:329-333.

Li N, Zong MH (2010) Lipases from the genus Penicillium: Production, purification, characterization and applications. J Mol Catal B:Enzym 66:43-54. 
Lowry RR, Tinsley JI (1976) Rapid colorimetric determination of free fatty acids. J Am Oil Chem Soc 53:470-472.

Mohamed SA, Abdel-Mageed HM, Tayel SA, El-Nabrawi MA, Fahmy AS (2011) Characterization of Mucor racemosus lipase with potential application for the treatment of cellulite. Process Biochem 46:642-648.

Molina G, Pimentel MR, Bertucci TCP, Pastore GM (2012) Application of fungal endophytes in biotechnological process. Chem Eng Transact 27:289-294.

Oliveira ACD, Watanabe FMF, Vargas JVC, Rodrigues MLF, Mariano AB (2012) Production of methyl oleate with a lipase from an endophytic yeast isolated from castor leaves. Biocat Agri Biotechnol 1:295-300.

Oliveira ACD, Watanabe FMF, Rodrigues MLF, Vargas JVC, Mariano AB (2013) Lipase production by endophytic yeast through factorial design. Acad J Microbiol Res 1:16-21.

Pandey A, Benjamin S, Soccol CR, Nigam P, Krieger N, Thomaz-Soccol V (1999) The realm microbial lipases in biotechnology. Biotechnol Appl Biochem 29:119-131.

Panuthai T, Sihanonth P, Piapukiew J, Sooksai S, Sangvanich P, Karnchanatat A (2012) An extracellular lipase from the endophytic fungi Fusarium oxysporum isolated from the Thai medicinal plant, Croton oblongifolius Roxb. Afr J Microb Res 6:2622-2638.
Salihu A, Alam MZ, AbdulKarim MI, Salleh HM (2012) Lipase production: An insight in the utilization of renewable agricultural residues. Resour Conservation Recycling 58:36-44.

Salihu A, Alam MZ, Karim MIA, Salleh HM (2011) Optimization of lipase production by Candida cylindracea in palm oil mill effluent based medium using statistical experimental design. J Mol Catal B:Enzym 69:66-73.

Sharma R, Chisti Y, Banerjeea UC (2001) Production, purification, characterization and applications of lipases. Biotechnol Adv 19:627-662.

Tan T, Lu J, Nie K, Deng L, Wang F (2010) Biodiesel production with immobilized lipase: A review. Biotechnol Adv 28:628-634.

Torres M, Dolcet MM, Sala N, Canela R (2003) Endophytic fungi associated with Mediterranean plants as a source of mycelium-bound lipases. J Agr Food Chem 51:3328-3333.

Tran DT, Yeh KL, Chen CL, Chang JS (2012) Enzymatic transesterification of microalgal oil from Chlorella vulgaris ESP-31 for biodiesel synthesis using immobilized Burkholderia lipase. Biores Technol 108:119-127.

Venkatesagowda B, Ponugupaty E, Barbosa AM, Dekker RFH (2012). Diversity of plant oil seed-associated fungi isolated from seven oil-bearing seeds and their potential for the production of lipolytic enzymes. World J Microbiol Biotechnol 28:71-80.

All the content of the journal, except where otherwise noted, is licensed under a Creative Commons License CC BY-NC. 